\title{
Rights versus obligations of persons detained in custody in Poland
}

\section{Introduction}

The provisions of Chapter XV of the Executive Penal Code (hereinafter referred to as the EPC or the Code) have fully taken into account the constitutional principle of the prohibition to violate human dignity, as the catalogue of the detainees' rights has been extended to guarantee their right of notification of their whereabouts, rights of defence, right to use their own clothing, underwear and footwear and food and hygiene products received from outside the detentions centre as well as the right of employment. On the other hand, the obligations of the detainees have been mainly brought down to the necessity to observe regulations and rules of order as well as carry out cleaning work within the premises of the detention centre ${ }^{1}$. At this point, it should be noted that almost identical modus operandi was adopted against the sentenced, taking into account differences in the application of this preventive measure, and in particular securing the proper course of criminal proceedings. In the case of detainees, the procedural principle of the presumption of innocence as the basis for treatment of the persons for whom no valid judgment on guilt and punishment has yet been issued must not be disregarded. Hence, the legislator has shown "liberalism" regarding, for instance, the issue of employing and remunerating those persons, their ability to use "non-prison" clothes, or

\footnotetext{
* Dr hab. Jerzy NikoŁajew - profesor na Wydziale Prawa i Administracji Uniwersytetu Opolskiego; e-mail:jerzy-nikolajew@wp.pl.

${ }^{1}$ Article 30 of the Constitution of the Republic of Poland explicitly outlines the principle of prohibition to violate personal dignity as applicable to everyone (see Constitution of the Republic of Poland of 02 April 1997, Journal of Laws of 1997, item 483 as amended). In turn, the provisions relating to detainees are laid down in Articles 207 - 223a (see the Act of 6 June 1997 - Executive Penal Code, Journal of Laws No. 90, item 557).
} 
exercising their procedural rights relating to the right of defence. Nevertheless, the necessity to secure the good of the investigation and to ensure the order and security at the detention centre imply the need to take into account, first and foremost, the directive for the absolute observance by the detainees of the rules and regulations in force in custody ${ }^{2}$. It also appears that the obligation of detainees to comply with the principles laid down in these regulations does not in any way affect their rights as set out in the Code.

On the other hand, in terms of terminology, it should be emphasized that the use of the Latin preposition versus in the title of this study does not necessarily mean taking into account the factor of "rivalry" between the rights and the obligations of the detainees, since the Polish legislator has practically managed to apply another meaning related to its meaning "towards" or "in the direction of" 3 . In fine, the legislator reached the effect of the proportionate interdependence between and obligations of these persons in connection with their detention. For these reasons, it was decided to address the above issues, which should also be taken into account, given to the need to provide adequate legal protection for the detainees.

\section{Right to notification of the whereabouts}

The EPC has introduced as a rule, whereby during the detainee's stay in custody, provisions on exercise of the custodial penalty shall be applied accordingly, taking into account the amendments referred to in Chapter XV of the EPC regarding detention on remand (Article 209 of the EPC). Hence, first of all, after the admission of a detainee to a detention centre, he or she should be informed immediately of his rights and obligations. In particular, a detainee should be allowed to familiarize with the provisions of the Code and the Organizational and Order Regulations regarding the execution of detention. In addition, there administrative obligations involving the requirement for the detainee to undergo appropriate medical examination and sanitary treatment (Article 210 of the EPC). However, the primary obligation of the detention centre's administration after admission of a detainee is to immediately notify the authority for which the detainee shall remain available, whereas the detainee shall enjoy the right to immediately notify a specific catalogue of persons. These include the closest person or another person, association, organization or institution as well as the detainee's lawyer. Nonetheless, the Code fails to define the concept of the clos-

${ }^{2}$ Regulation of the Minister of Justice of 25 August 2003 on the organizational and order regulations governing detention on remand, Journal of Laws No. 152, item 1494.

${ }^{3}$ K. Kumaniecki (edition), Słownik łacińsko-polski, Warsaw 1997, p. 299. 
est person, as earlier this definition appeared in Article $115 \$ 11$ of the Penal Code, and on that basis, the closest person is "spouse, ascendant, descendant, sibling, relative in the same line or degree, adopted person and his/her spouse, and a life partner"4. Article $211 \S 1$ of the EPC does not specify the methods of contact between a detainee and those arrested persons, which in practice can mean a variety of forms of such contact. After 01 July 2015 and following the amendments to the EPC, a lawyer can contact a detainee via phone not only after being admitted to the detention centre but also throughout the detainee's stay in custody. In the case of closest persons or other people, telephone contact seems to be the simplest solution, except that the legislator omitted detailed issues that may in fact be decisive in the exercise of this right. At this point, it is necessary to take into account, in particular, the practical aspects of detention and deprivation of the detainee of his or her personal belongings, including the detainee's mobile phone. Hence, after depositing a mobile phone, the obligation to make the phone available should rest with the officers of the Prison Service (hereinafter: PS), who carry out the activities associated with accepting the detainee into custody. On the other hand, it is still a matter of controversy to regard mobile phones as valuable items, as according to the regulation of the Minister of Justice, mobile phones do not fall within this category ${ }^{5}$. Therefore, it seems that allowing contact, including phone calls with the closest person or another person, is the domain of the detention centre and not the "problem" of the detainee. A hypothetical solution in this case could be letter correspondence providing information to the detainee's closest persons about his or her detention, but then such correspondence would be subject to censorship by the disposing authority, which would significantly increase the notification process and would divert the idea of prompt notification. Yet another problem concerning the information about the detainee's stay in custody may concern associations, organizations or institutions. First of all, it is not clear what kind of entities should be taken into account in this case: whether abstract or concrete ones, with which a detainee is institutionally or freely associated. Secondly, the administration of the detention centre or the disposing authority has no actual ability of verifying this type of relationship. Thirdly, there is no indication how such information is to be communicated. On the other hand, in the case of a letter sent by a detainee to such an association, organization or institution, a control procedure should be initiated by the disposing authority. Therefore, the detainee's right for prompt notification of his or her whereabouts following

\footnotetext{
${ }^{4}$ See Act of 06 June 1997 - Penal Code, Journal of Laws No. 90, item 555, as amended.

${ }^{5}$ Regulation of the Minister of Justice of 27 October 2003 on administration and financial settlements related to maintenance of the deposit of valuables and cash of persons deprived of liberty (Journal of Laws No. 192, item 1881).
} 
his or her admission to the detention centre may turn out to be illusory and certainly difficult to exercise $\mathrm{s}^{6}$.

More difficulties may arise in the case of a detainee who is not a citizen of the Republic of Poland. Although Article $211 \S 2$ of the EPC formally allows a foreign detainee to notify the relevant consular post or of diplomatic mission of the fact of his/her stay in custody but no measures for exercising such a right have been indicated. Therefore, they are left with the notification methods mentioned in the previous paragraph concerning the closest persons, specific entities and the lawyer of a detainee, who is a Polish citizen. In addition, a foreign detainee enjoys the same rights as a Polish citizen to immediately notify the detainee's closest persons, other persons, associations, organizations or institutions as well as a lawyer. In the case of foreigners, additional difficulty is related to their use of a foreign language, which incomprehensible for the detention centre officers engaged in admission of the detainees (e.g. Arabic) ${ }^{7}$.

It should also be borne in mind that the right provided for in Article $211 \S 2$ of the EPC, regarding prompt notification of detention is not the same as the detainee's right to identify the persons with whom he / she wishes to maintain contact while in detention. The catalogue of these persons may be much broader, but each time their visits will be subject to the consent of the detention centre authorities, which will determine, by way of an order, the manner and nature of such a visit. Information on these issues has been also included in the "Handbook for detainees, sentenced, punished and foreigners" prepared by the Prison Service. Such multipage brochures should be found in every so-called "detention cell", where the detainees are placed immediately after their admission to the detention centre ${ }^{8}$.

Similar instruction concerning the notification of appropriate persons and authorities of the detainee's stay in custody has been prepared for the prosecutor's offices and its contents are communicated to persons already at the stage of issuing the statement of charges ${ }^{9}$. However, this type of instruction may be

${ }^{6}$ P. Pałaszewski, Przyjęcie tymczasowo aresztowanego do aresztu śledczego, „Nowa Kodyfikacja Prawa Karnego" vol. XXV, Wrocław 2009, p. 228.

7 L. Bogunia, Kluczowe zagadnienia wykonywania tymczasowego aresztowania, „Nowa Kodyfikacja Prawa Karnego", vol. XVIII, Wrocław 2005, p. 303.

${ }^{8}$ www.sw.gov.pl/Data/Files/kunickim/informatory-dla-cudzoziemców/polski_2014. pdf [accessed on: 7/05/2017].

9 For instance, the sample "Suspect's Instruction on the Rights and Obligations", as prepared by the Regional Prosecutor's Office in Poznań, stipulates that the detainee in the criminal proceedings has the right to "notify the closest person as well as the employer, school, university, commander, or the manager of the company owned by the detainee or the company for which he/she is responsible, about the detention on remand (Article $245 \$ 2$, Article $261 \$ 1$ and 3 of the Code of Criminal Procedure)". The foregoing shows that in this case, an expansive interpretation of the so-called glossary of the penal code has been applied and the closest persons have been deemed to include also entities not mentioned in the act (employer, university, school, commander) - www.poznan. pr.gov.pl/?m=prawa-i-obowiazki-podejrzanego\&ide $=29$ [accessed on: 7/05/2017]. 
premature in the event where the preventive measure in the form of detention on remand is not used for the suspect. In any case, the suspect (the accused) may himself/herself indicate the closest person he/she wants to inform about his/ her detention on remand (Article $261 \$ 1$ of the Code of Criminal Procedure) ${ }^{10}$. However, as a rule, the court shall agree to the request of the suspect (the accused) and notify the indicated closest person of his/her detention. It is also acknowledged that the court should notify more than one person about the detainee's custody, if the need arises from the circumstances of the case or is reasonably justified by the applicant (the detainee) $)^{11}$.

The above narrative shows that not only the detention centre administration but also the court issuing the detention order should notify the detainee's closest person of his/her detention. Such a model is intended to reassure those closest to the detainee on the possibility of contacting him/her and at the same time allow them to take steps to appoint a defence counsel for the suspect (accused) by another person (in this case the closest one). However, it should be noted that the detainee, upon admission to the detention centre, may not benefit from the privilege referred to in Article $211 \$ 2$ of the EPC, since the rule laid down in that provision has the characteristics of only the right, and not the obligation of a detainee. Therefore, in the case of passivity on the part of the detainee, he or she cannot be forced to take any such actions. No contact with the family or lack of such family (closest persons) must not be an obstacle limiting the right of the suspect (accused) to use assistance from the defence counsel or to appoint a lawyer ex officio in such a situation ${ }^{12}$.

\section{Right of defence}

It appears that the principle of the right of defence is in fact the principle arising from the procedural law and, to a lesser extent, from the Executive Penal Code. This follows, among others, from the wording of Article 6 of the Code of Criminal Procedure under which "the defendant has the right to defence, including the right to use the help from the counsel, of which he/she must be instructed". However, in the implementation of the detention order, the aforesaid procedural right concerns the exercise of a preventive measure applied under the conditions of detention and, in that sense, is an important enforcement measure. Generally, the right of defence covers the period from the initiation of the first actual actions against a particular person (even without a statement of charges) until the end of the criminal procedure and also applies to the enforcement of

${ }^{10}$ Act of 06 June 1997 - Code of Criminal Procedure, Journal of Laws No. 90, item 556, as amended.

${ }^{11}$ R. Stefański, Środki zapobiegawcze w nowym kodeksie postępowania karnego, Warsaw 1998, p. 77.

${ }_{12} \mathrm{~K}$. Eichstaedt, Wykonanie postanowienia o zastosowaniu i przedłużeniu okresu tymczasowego aresztowania, „Prokuratura i Prawo” No 4/2009, pp. 106 -107. 
court decisions. In addition, the right of defence for "everyone" expressed in Article 42 paragraph 2 of the Constitution makes it a standard element of the democratic lawful state, where it is formally permissible to undertake procedural actions arising from material and formal defence, both by the defendant himself/herself and with the assistance of a defence counsel. This type of right is very "helpful", especially to those suspected and accused, whose freedom of action has been limited by their placement in custody ${ }^{13}$.

One of the basic privileges that "fit into the specifics" of the detainees' rights to defence is his/her right to information and hearing. It involves obtaining of comprehensive and immediate information from the person concerned on the reasons for detention and arrest. In addition, detainees (remanded in custody) have been given the right to hear them, which is not equivalent to and should not replace the suspect's interrogation ${ }^{14}$.

Subsequent powers for the exercise of the right of defence are relating to the statement of charges and after the amendment of the Code of Criminal Procedure i.e. after 01 July 2015, the instruction on the rights and obligations of the suspect has been extended to include a request for a hearing in the presence of the defence counsel, thereby significantly strengthening the suspect's position, in particular during his/her stay at the detention centre ${ }^{15}$.

In addition, the right of defence includes also the defendant's right to file applications and participate in litigation procedure, the right to challenge procedural decisions on detention and the right to use an interpreter. Especially, the issue of free interpretation services during criminal proceedings has particular practical significance in the case of foreign detainees and from the point of view of the right of defence appears to be a primary requirement. The obligation to provide the interpreter's assistance does not rest with the administration of the detention centre but with the disposing authority (court, prosecutor's office). The authority should also serve the defendant with a translation of the statement of charges (including supplements or amendments, if any), judgments to be appealed and the final decisions terminating the proceedings. The detainees may exercise their right of defence also by attending court sessions concerning their detention. After all, a detainee has the status of a party, which also extends to his/her right to participate in the appeals procedure ${ }^{16}$.

${ }^{13}$ D. Dudek, Konstytucyjna wolność człowieka a tymczasowe aresztowanie, Lublin 1999, p. 202.

${ }_{14}$ Wałach, Uprawnienia procesowe zatrzymanego i tymczasowo aresztowanego $w$ świetle zasady prawa do obrony, Białystok 2014, pp. 110-111 - www.repozytorium.uwb.edu.pl/jspui/ bitstraem/11320/3129/1/pracadoktorska.pdf [accessed on: 15/05/2017].

${ }_{15}$ P. Wiliński, Zasada prawa do obrony w polskim procesie karnym, Krakow 2006, p. 39.

16 P. Nowak, Zasady porozumiewania się zatrzymanego $z$ adwokatem oraz tymczasowo aresztowanego $z$ obrońca $w$ Kodeksie postępowania karnego $w$ aspekcie konstytucyjnym oraz prawnomiędzynarodowym, „Czasopismo Prawa Karnego i Nauk Penalnych”, ed. 1/2013, p. 89. 
At the same time, it should be noted that there is quite an extensive set of procedural rights vested with the detainees, as regards the so-called formal defence. These include the detainee's right to contact the defence counsel, the right to use the lawyer's assistance and the right to choose the lawyer, the right to appoint a counsel ex officio, the right to use assistance of a legal representative, the right to communicate with the counsel, and to prepare for defence. The detainee's right of defence may also be exercised by notification to the counsel and the latter's participation in the court's session concerning detention as well as through the counsel's rights arising from the attorney-client privilege ${ }^{17}$.

Special attention should be paid, in particular, to the practical aspect of the detainee's right of defence as regards the exercise of their right to communicate with the counsel and the attorney. In 2010 and 2011, the Ombudsman has accused the Director-General of the Prison Service of the practices restricting such contacts, particularly, where a detainee has been imprisoned in an isolation cell, or in the event of refusal of contacts with a defence counsel, attorney, solicitor or notary. The Ombudsman meant to convince prison directors that they were not allowed to deny such contacts if the defence counsels (in the broader sense) showed their official ID cards and the visit was to take place in the room intended for procedural activities during the working hours of the detention centre administration. In addition, in correspondence with the Ombudsman, the Director-General of the Prison Service rightly admitted that the manner of such contact differs significantly from the contacts with e.g. the closest persons, since apart from the fact that the place is a separate room intended for procedural activities, there are also no time limitations. Other doubts concerned issues related to the monitoring of such rooms and carrying out by the Prison Service officers of personal and luggage checks of defence counsels entering the so-called restricted detention area. According to the Ombudsman, such behaviour could violate the attorney-client privilege, as previously referred to by the Supreme Bar Council (hereinafter referred to as the SBC), which has already been familiar with the cases of using industrial cameras installed in detention centres in a manner contrary to the applicable legal regulations. The SBC members 'concerns also stemmed from the fact that police officers previously recorded conversations between lawyers and their clients and then used them during proceedings and further disclosed the same in the media ${ }^{18}$.

${ }_{17}$ D. Tarnowska, Prawo tymczasowo aresztowanego oskarżonego do kontaktowania się ze swoim obrońca, „Prawo i Prokuratura” No 12/2003, p. 141.

${ }_{18}$ M. Kolendowska-Matejczuk, Konstytucyjne prawo do obrony w działalności Rzecznika Praw Obywatelskich, Warsaw 2013, p. 34. It should be noted that the dispute between the Prison Service and the Ombudsman arises primarily from the fact that the prison officials firmly claim that they fully comply with the provisions of the EPC and the Organizational and Order Regulations for detention on remand, as regards the exercise of the detainees' rights to contact their defence counsels. The Ombudsman's negative opinion, as referred to above, is based on the results of 


\section{Right to use own clothing, underwear and footwear}

Article $216 \$ 1$ of the EPC provides for the detainees' ability to use their own clothing, underwear and footwear. The only condition limiting this type of entitlement may be that it should neither interfere with the order, nor contravene security or the sanitary regime at the detention centre. At the same time, directors of detention facilities have been given the opportunity to exercise control in this regard by vesting them with the power to determine the quantity and type of clothing, underwear and footwear that a detainee may have in a cell ${ }^{19}$.

The foregoing shows that the detainee's right to use his own non-prison clothing is a consequence of accepting the procedural principle of the presumption of innocence. Therefore, the detainees are allowed to use their own garment while in custody, since the prison clothes are intended exclusively for convicts, and mostly in closed-type establishments. However, in the case of inability to use their own clothing (including footwear and underwear), for example due to their lack, and the inability to deliver them to the detention centre by the detainee's family, the detention centre administration is obliged to provide the detainee with appropriate clothing, footwear and underwear, taking into consideration the relevant season of the year, from the detention centre's resources, in accordance with the standards established under the provisions on the uniforms for those detained in custody. As a consequence, a detainee will be using temporarily the same "clothes" as the convict. On the other hand, in practice, it will be difficult to identify such a detainee among other convicts, especially when they are away from the cell and remain at penitentiary establishments, in which the convicts and the detainees stay at the same time (although in separate divisions) ${ }^{20}$.

inspections carried out within the framework of the National Prevention System, while the postinspection recommendations are sent to the Ministry of Justice, which officially supervises the operation of the Prison Service. In addition, the Ombudsman performs inspections based on the system of complaints of persons deprived of their liberty, including those temporarily detained. A contentious issue, at least until 01 July 2015, was the issue of telephone contacts between a detainee and his/her defence counsel. Previously, the Director-General of the Prison Service also argued to the Ombudsman that the actions of the officers and employees subordinate to him were lawful as regards the contacts between detainees and their defence counsels. In addition, the new deputy Ombudsman (since September 2015), Krzysztof Olkowicz, retired colonel of the Prison Service and former District Director of the Prison Service in Koszalin, against whom criminal proceedings were conducted, later discontinued, for recommending his secretary to pay the fine for a person serving substitute custodial sentence (the offender stole a candy bar worth ca. PLN 5), announced that he would monitor the exercise by the Prison Service of the obligation to ensure proper conditions for implementation of the detainees' rights of contact with their defence counsels. See A. Łupińska, Krzysztof Olkowicz zastępca RPO, „Forum Penitencjarne” No 10/2015, p. 4.

${ }_{19}$ See $\$ 14$ paragraph 2 pt. 7 of Regulation of the Minister of Justice of 25 August 2003 on d the organizational and order regulations regarding the execution of detention.

${ }^{20}$ J. Kosonoga, Podstawy stosowania środków zapobiegawczych, „Prokuratura i Prawo” 2003, No 10, p. 26. 
The use of one's own clothes by detainees is especially visible in situations involving their participation in the visits and attendance to the court hearings as well as in other procedural activities outside the detention centre. Especially at the courts, these persons should have the opportunity to appear without stigmatization of "clothing" associated with their stay in custody and not to be distinguished among other defendants, who have not been detained on remand. On the other hand, the above rule no longer applies in the case of detainees having a status of a dangerous prisoner. In such a case, every leave from a cell (visit, walk, procedural activities etc.) necessitates the use of a red or orange uniform, and not his/her own clothes ${ }^{21}$.

More, though slightly different kind of doubts concerning clothing may arise in situations related to safety or sanitation issues. Although the provision does not explicitly stipulate that this is a privilege reserved for the director of a detention centre, it appears obvious from the functional interpretation that the concept proposed by the legislator is underdefined in the case of this provision. The "safety and sanitation" clauses may after all be abused and used contrary to the intention of the legislator by the authorities applying such legal standards. In fine, introduction of the obligation for the detainees to use prison clothing (instead of their own) may lead to violation of the principle of such treatment and to possibility of resolving criminal proceedings involving acquittal of the accused. Similar unclear considerations have led to the introduction of restrictions on the use of such garment due to health hazards. In fact, the same risk may be posed by dirty and hygienically contaminated clothing and underwear, both owned by the detainee and provided by the detention centre. Therefore, it seems that the legislator's rigorous approach in this regard has no justification, but merely expresses the recognition of the detention centre's dominant position towards detainees, by ordering them to wear the prison uniforms $\mathrm{s}^{22}$.

It is also worth noting in this context the role of the detention centre director in this regard, who by means of an administrative order determines the quantity and type of objects that a detainee may temporarily hold in a residential cell. Therefore, the redundant (but only in the subjective opinion of the administrative detention centre) quantity of clothing, underwear and footwear and its assortment, which does not reflect the actual needs of the detainees, should result in the decision of the detention centre director or his/her authorized representative to deposit such items in the warehouse or to hand over them to the closest persons e.g. during visits (unless these items are included in the category of evidence in the pending criminal proceedings). The director's decision to restrict the use

${ }^{21}$ S. Przybyliński, Więźniowie „Niebezpieczni”-ukryty świat penitencjarny, Krakow 2012, p. 17.

${ }_{22}$ T. Szymanowski, Bezpieczeństwo w wykonywaniu kary pozbawienia wolności i tymczasowego aresztowania w świetle przepisów prawa, [in:] T. Bulenda, A. Rzepliński (ed.), Modernizowanie więziennictwa. V Kongres Penitencjarny, Warsaw 2015, p. 75. 
of own clothing may also be justified in situations where the cell's living space is limited and it is not possible to store personal belongings of the detainees. In practice, this means that the directors of the detention centres, in their internal order regulations, usually quite precisely (albeit modestly) determine the quantities of items included in the assortment of the prisoners' clothing. However, this does not preclude making decisions that take into account the requests of detainees to increase the number or kind of objects at the disposal of the detainees or exceeding the framework of the detention centre's internal order ${ }^{23}$.

An instrument useful for this purpose is the so-called 'clothing parcel' comprising one's own clothing, underwear and footwear. In order to exercise this right, it is sufficient to obtain a clothing voucher and prepare the parcel according to the list of items to be included therein. However, in this case, the legislator did not specify the size of the parcel or the frequency of its sending, and contrary to the food parcels, allowed complete freedom to the authorities of the detention centres. Hence, the most commonly used practice is to assume that a detainee is allowed to receive one clothing parcel per month. For pragmatic reasons, its size is set at 3 or 5 kilograms, although e.g. some detention centres adopted no quantitative or qualitative restrictions in this regard (for example, at the detention centre in Mysłowice, clothing parcels are accepted in any quantities and at all times $)^{24}$. This type of information is made public in messages for prisoners as well as on the prisons' websites under the tab concerning parcels. However, complete liberalization in the provision of prisoners' clothes, underwear and footwear in parcels may be limited by the administrative supervision and control of the clothing vouchers issued to prisoners in such a way as to take into account the detainee's living conditions, clothing store capacity and at the same time satisfy safety and sanitary requirements at the detention centres ${ }^{25}$.

It is also important to note the rule set forth in Article $216 \$ 3$, which provides for the intervention of the body at the disposal of which the detainee temporarily remains, in such a way that it is possible to restrict or determine how that body exercises its powers. In practice it means that, for example, in the detention order the disposing authority may require the detainee to use the prison clothing at every place and at all times while in custody. Therefore, the principle set out in Article $216 \$ 1$ cannot be treated as an absolute rule and qualified as fully guaranteeing the detainees' rights to use only their own clothing resources ${ }^{26}$.

${ }^{23}$ O. Horna, Bezpieczeństwo jednostek penitencjarnych a zadania dla personelu, [in:] W. Ambrozik, H. Machel, P. Stępniak (ed.), Misja Stużby Więziennej a jej zadania wobec aktualnej polityki karnej i oczekiwań społecznych, Poznań-Gdańsk-Warsaw 2008, p. 321.

${ }^{24}$ www.zamuramizk.pun.pl/as-myslowice-251.htm [accessed on: 9/05/2017].

${ }_{25}$ M. Kuć, M. Gałązka, Prawo karne wykonawcze, Warsaw 2009, p. 209.

${ }_{26}$ T. Bulenda, Z. Hołda, A. Rzepliński, Prawa człowieka a zatrzymanie i tymczasowe aresztowanie w polskim prawie i praktyce jego stosowania, „Archiwum Kryminologii” 1992, vol. XVIII, p. 66. 


\section{The right to use food, medicinal and hygienic products obtained from outside the detention centre}

The national legislator laying down the executive penal provisions decided that the issues related to providing suitable social conditions to the detainees should not in any way impose any burden on themselves, since it is the obligation of the state authorities, which decided to isolate those persons against their will but for the sake of the law enforcement. Therefore, it has been decided that their boarding should be in line with specific calorific, weight and dietary standards common to all prisoners and detainees irrespective of their legal status. Consequently, uniform rules of nutrition have been adopted in the relevant legislation $^{27}$. It results primarily from the daily caloric value of food $(2,600 \mathrm{kcal})$ in foodstuffs (up to $2,800 \mathrm{kcal}$ for those under 18). In addition, the percentage of nutrients broken down by protein, fats and carbohydrates and the daily value of vegetables in meals delivered from prison kitchens have been determined in detail ${ }^{28}$. In addition, nutritional regulations provide for the possibility of receiving meals according to appropriate standards and diets. Consequently, prisoners' nutrition regime provides for basic standard, diets for juveniles and those employed in severe conditions as well as easily digestible and diabetic diets (patients with insulin dependent diabetes, in addition to meals provided for in the diabetic diet, receive $6 \mathrm{~g}$ of solid sugar per day at breakfast). Also, the "nutrition" regulation determines a strict list of products prohibited in preparation of light and diabetic diets. Another form of improvements related to nutrition of sick prisoners includes medical recommendations for individual nutrition, determining e.g. number and hours of meals, daily calorie content, percentage of nutrients, prohibited food preparation methods and the list of prohibited products. Another right closely associated with nutrition is the right to demand extra drinks when a detainee stays in a room where the temperature caused by weather conditions exceeds 28 degrees Celsius ${ }^{29}$.

At the same time, the legislator allowed the detainees to receive medical and hygienic products from the detention centre's resources, and in exceptional circumstances allowed them to obtain these resources from outside. In the case of medicinal products, it is not only medicines but also dressings, disin-

27 See Regulation of the Minister of Justice of 2 September 2003 on the definition of the daily standard nutrition value and the types of diets issued to persons imprisoned in prisons and detention centres, Journal of Laws No. 167, item 1633, as amended.

${ }^{28}$ The term "delivered from prison kitchens" can be imprecise today, as part of penitentiary and detention centres have given up "cooking on the spot" in favour of the meals delivered to prisons by catering companies.

${ }^{29}$ K. Postulski, Kodeks karny wykonawczy. Komentarz, Warsaw 2015, p. 1057. 
fectants, prostheses and equipment necessary for rehabilitation. On the other hand, hygienic products include items necessary for daily personal hygiene ${ }^{30}$.

In addition to the entitlement to receive meals as well as medicinal and hygienic products provided by the detention centre administration, as a rule, in Articles 216 paragraph 2 of the EPC, the legislator provided for an option to deliver these items from outside the detention centre as a unique situation. Double consent is also required from the disposing authority and the director of the detention centre. In addition, the disposing authority may limit or specify how these rights are exercised, whereas such powers are no longer available to the director of the detention centre. The control exercised by the detention centre's management is brought down to determination whether these objects may pose a threat to the security of detention centre, while the inspections carried out by the disposing authority are based on the indications whether possession of such items which may hinder criminal proceedings. Each time, the detainees' freedom of decision-making as regards the choice of specific i.e. alternative to the prison ordered food, medicinal or hygienic products is limited.

Accordingly, the detainees are forced to use cheap meals, the same medicines as well as hygienic and cosmetic products. This, however, does not limit their social rights in any way, since the administrators of the detention centres generally provide them with the basic assortment of food and medicinal and hygienic products. The quality of food delivered and items treated as medicinal and hygienic products can be subject to complaints from prisoners. However, each time it is necessary to consider whether the standards laid down in the regulations, and not the subjective feelings of the detainees as regards the quality of meals or the effectiveness of the treatment of patients at detention centres, have been met $^{31}$.

\section{Right to visits, parcels, correspondence and telephone contact}

This type of rights concerns the detainees' right to contacts with the outside world. Given the isolating nature of the detention on remand, the rights to visits, parcels, correspondence and telephone contacts are subject to strict control by the disposing authority and the detention centre administration, while their volume (frequency) and methods of implementation are regulated. Especially

${ }^{30}$ J. Zagórski, Wykonywanie tymczasowych aresztowań w Polsce, „Państwo i Prawo” 2007, ed. 10, p. 40.

31 T. Kalisz, Wybrane problemy związane $z$ wykonywaniem tymczasowego aresztowania: status prawny osoby tymczasowo aresztowanej, [in:] B. Stańdo-Kawecka, K. Krajewski (ed.), Problemy penologii i praw człowieka na początku XXI stulecia: Księga poświęcona pamięci Profesora Zbigniewa Hołdy, Warsaw 2011, p. 400. 
the manner for allowing visits with detainees has a major impact on the status of detainees, so the legislator paid a lot of attention to these issues in the extended norm under Article 217 paragraph 1 of the EPC (especially after 01 July 2015). This provision determines the frequency of visits of at least one per month and only with the closest person. Decisions are made by the disposing authority, and where a detainee remains at the disposal of several authorities, consent is required from all of them unless the authorities decide otherwise. However, in the cases referred to in Article 217 paragraph $1 \mathrm{~b}$ of the EPC, a consent to a visit may be refused. This refers to situations, where visits may be used to illegally impede criminal proceedings, or to commit a crime, in particular, to instigate a crime. A refusal of the consent can be challenged at the court or at the prosecutor's office, and such a right applies to the detainee and the person wishing to attend the visit. However, if the contested order on refusal of the consent to a visit is upheld, then the legislator has provided that lodging a complaint against the refusal to consent to the visit of the same person to the detainee within three months of issue of the order upheld in force, is unacceptable. In addition, Article 217 of the EPC defines special rules for visits with the minors (civilian concept of persons under 18). Then consent to visit is dependent on the application of the statutory representative. Conversely, for persons under the age of 15, the visits require presence of a legal representative or an adult closest person, or possibly, such a visit may take place under the supervision of a designated representative of the Prison Service ${ }^{32}$.

As a rule, it has been assumed that visits shall take place under the supervision of a prison officer in such a way as to prevent direct contact (through the net, glass, or intercom). Then, a detainee may also consume the meals and beverages purchased from the local canteen. On the other hand, a disposing authority may define, by way of an order on grating the right to a visit, a different method facilitating the direct contact between a detainee and visitors, but at the request of the visitor, the visit may take place in a traditional manner i.e. without direct contact. In addition, in the case of detainees posing a serious threat to order and safety, the prison administration is obliged to inform the disposing authority of the risk to the visitors and that it is necessary to allow visits in a manner preventing direct contact with the detainee (Article 217 paragraph 5 of the EPC). In turn, in Article 217 paragraph 6 of the EPC, the legislator provided for yet another possibility for intervention of the disposing authority in the detainees' contacts with the outside world, involving contacts with the clergy providing religious services at the detention centre's premises. The, the disposing authority may decide to limit such contacts or determine the manner of such contacts (e.g. in the form preventing direct contact). It appears,

${ }^{32}$ M. Kuć, M. Gałązka, Prawo karne wykonawcze, p. 210. 
however, that such restrictions must remain in contradiction to the axiology of the protection of human rights laid down in Articles 8 and 9 of the European Convention on Human Rights (hereinafter: ECHR) ${ }^{33}$.

Detainees pending trial are also given the right to receive food parcels. However, it should be noted that this type of entitlement has not been guaranteed under the law (EPC), but follows from the provisions contained in paragraph 23 (1) of the Rules of Detention on Remand. As a principle (though providing for derogations), it has been assumed that the parcel should not exceed $5 \mathrm{~kg}$ (including packing) and can be received by a detainee once a month. The content of the parcels shall be checked in the presence of a detainee and the items which cannot be verified without substantially affecting their substance and the items in packaging impeding the control of their content shall be excluded from the parcel. It is also possible that a physician or another qualified health care specialist at the detention centre may determine the food as unfit for consumption and then destroy the same in the presence of a detainee. Apart from food parcels, it is also possible to receive a parcel with clothing, underwear and footwear as well as hygiene products and medicines ${ }^{34}$.

The issue of availability or lack of availability of food parcels have been placed in the catalogue of rewards and disciplinary penalties. Article 221 paragraph 2 point 3 of the EPC stipulates that a reward may be an additional food parcel or a parcel in excess of the permissible weight, while Article 222 paragraph 1 point 3 of the EPC provides for deprivation of the possibility of receiving one food parcel in the quarter immediately following the quarter in which a penalty ordered has been considered as a disciplinary penalty ${ }^{35}$.

In addition to the right to visits and parcels, detainees also have the right to correspondence. However, unlike the previous powers, it has been decided to adopt highly restrictive solutions, given the nature of the detention on remand. Generally, all the so-called non-official correspondence is subject to mandatory control by the disposing. In Article 217a paragraph 1, the legislator decided to use constructions, later undefined in the so-called glossary, associated with the control of the detainees' correspondence (these include "withholding", "censorship" and "supervision") and did not specify the rules for taking activities, which actually interfere with the personal rights of the detainees. In addition, the Code (Article 217) provides that the official correspondence is not subject to censorship and may be sent to the addressees listed in this provision. The

${ }^{33}$ M. A. Nowicki, Wokół konwencji europejskiej. Komentarz do Europejskiej Konwencji Praw Człowieka, Warsaw 2009, p. 78-80.

${ }^{34}$ W. Śledzik (ed.), Prawo penitencjarne. Kodeks karny wykonawczy z przepisami wykonawczymi i zwiazkowymi, Zakamycze 2006, p. 538.

${ }^{35}$ K. Kowaluk, Dodatkowy sposób realizacji paczek z żywnością dla osadzonych, „Forum Penitencjarne" No 2/2012, p. 14. 
catalogue of these persons includes defence counsels or attorneys being lawyers or legal advisors, the Ombudsman, the Children's Ombudsman and other bodies under the ratified international agreements, law enforcement agencies, judicial bodies, state and local authorities. However, such an extensive inclusion of the entities, especially the latter ones, seems unreasonable ${ }^{36}$.

It must also be kept in mind that before the amendment of the EPS, there was a rather strict rule that prohibited the detainees' use of phones and contacting anyone from outside the detention centre. After 01 July 2015, the legislator opened a "gateway" for contacts with a defender and allowed telephone calls, which would be possible after obtaining the prior approval of the so-called disposing authority. In the event, where a detainee remains at the disposal of several authorities (e.g. courts of different instances or prosecutor's offices), the consent of each of them is required unless the authorities agree otherwise. This does not mean that the authorities are obliged to issue only decisions, which are in line with the detainees' requests. There is also a formula for the negative handling of such requests, primarily for the sake of the investigation. A negative indication may also include a legitimate fear that a permission to use a telephone can be used to illegally impede the conduct of criminal proceedings or even commit a crime. In particular, this may also include instigation to commit a forbidden act. Undoubtedly, the circumstances providing the basis for refusal in such a situation may be a situation, where the indications underlying detention on remand include inducing false testimony or other unlawful impeding of the proceedings ${ }^{37}$.

In addition, the detainees have been allowed to file a complaint against a refusal to use such contact with a defence counsel. The competent authority in this situation is the court at whose disposal the detainee remains, and in the case of orders issued in this regard by the public prosecutor, the complaint shall be examined by the supreme prosecutor. On the other hand, it is obvious that the legislator excluded the possibility of other forms of contact with the use of wired or wireless communications (e.g. via text messages, mails, social messengers).

Attention must also be paid to the legal and factual situation associated with the telephone contact with persons detained on remand prior to the discussed amendment of the Code. It is necessary to refer to the role of the Ombudsman, who already since 2008 has been heralding the difficulties posed by the Prison Service in maintaining the contacts between the detainees and their defence counsels, in order to better understand the intentions of the legislator to amend

${ }^{36}$ M. Płachta, Prawnomiędzynarodowe i konstytucyjne podstawy ochrony praw oskarżonego $w$ procesie karnym, „Gdańskie Studia Prawnicze” 1999, vol. IV, p. 25.

${ }^{37}$ J. Wierzbicki, Telefony dla tymczasowo aresztowanych? „Forum Penitencjarne” No 8/2014, p. 16. 
the Executive Penal Code in that direction. This involvement of the Ombudsman in the above matter was connected with the operation of the National Preventive Mechanism and the findings of the inspection visits conducted at the detention centres, as a result of which it was held that the Prison Service misinterpreted the content of Article 217c of the EPC, as the then legislation undeniably allowed those detained in custody to contact their defence counsels by phone. The employees of the Office of the Ombudsman indicated that the prohibition to use telephones and other means of wire and wireless communications by detainees must not extend to contacts with a counsel or an attorney being a solicitor or a legal adviser. They referred to the provisions laid down in Article 215 paragraph 1 of the EPC concerning the right to communicate with the defence counsel in the absence of others. The lawyers employed in the prison services were arguing this thesis, pointing out that had the legislator wanted such a solution, it would have been pointed out explicitly. In addition, it was argued that the Prison Service is an enforcement body and therefore cannot meet the expectations formulated only by the recommendations of the National Preventive Mechanism. In view of such a position of the Director-General of the Prison Service, the Ombudsman asked the Constitutional Tribunal to declare the non-conformity of Article 217c of the EPC with the basic law. Although a lot of time has passed since filing of this application (15 November 2013), the Constitutional Tribunal has not managed to rule on the case due to intermittent events. (On 15 May 2014, the Upper House of the Polish Parliament (Sejm) received a governmental draft amendment to the EPC, Parliament Printout No. 2393 and the first reading took place on 10 June) ${ }^{38}$.

\section{Right to employment}

The Code does not in any way impose an obligation on the detainees to work, but treats the employment only as the right available to the detainees. Article 218 of the EPC provides for two forms employment of detainees: paid and unpaid. In each case, however, a detainee's consent is required, and employment itself can take place both within and outside the detention centre's premises. In the case of employment outside of the detention centre, it is also necessary to obtain the employment approval issued in the form of an order issued by the disposing authority. The employed detainees are subject to the same principles of remuneration as to other employees not being detainees, except for deductions related to the requirements under Article 125 paragraph 1 of the EPC (10\% for the Victims and Post-Penitentiary Assistance Fund and 25\% for the purposes

${ }^{38} \mathrm{~J}$. Wierzbicki, Telefony dla tymczasowo aresztowanych? p. 16. 
of the Fund for the Professional Activation of the Convicts and Development of the Prison Employment Establishments). The foregoing shows that the type and amount of deductions from the remuneration received by the detainees can be an effective barrier in taking up any paid employment. In addition, another setback for employment may also be the little attractive job offers on account of a limited number of jobs at the premises of the detention centres and the lack of sufficient interest from outside contractors. Undoubtedly, the general difficulties in the labour market also apply to those in custody ${ }^{39}$.

\section{Obligation to comply with regulations and rules of order}

It is must be clearly emphasized that the parts of the EPC concerning the persons detained in custody do not explicitly articulates the provisions necessitating the detainees to surrender to specific obligations, and those which have been provided for, are dispersed in different places. However, the basic obligation of this group of prisoners seems to be the need to comply with the requirements of the law, internal rules of procedure or the internal rules of order, as in force at the detention centre. After analysing the provisions contained in particular groups of regulations, it turns out that the least number of these obligations has been included in the executive penal act. On the other hand, organizational and order regulations include several obligations that are different in terms of their type. First and foremost, they include the obligation to surrender to activities related to admission to the detention centre and placement in the residential cells. In addition to this obligation, the prisoners should follow the rules arising from the internal regulations governing the organization of reception of correspondence and management of visits as well as treatment, bathing, sanitation, shopping at the detention centre, walks, meals, appeals, smoking ban, rules of movement and prohibition of contact with others, depositing valuables at the detention centre's warehouse, and religious meetings ${ }^{40}$.

Similar obligations have been laid down in the internal rules of the detention centres, which specifically "clarified" various responsibilities of detainees. These include, but are not limited to obligations related to assemblies, sleep and rest periods, sports and cultural activities, regime of visits, shopping in a canteen, attending religious services, contacting people from outside of the detention centre, filing complaints and requests. In general, the detainees' obligation is to adhere to these principles, which as a rule are intended to secure the proper

39 T. Kalisz, Zatrudnianie nieodpłatne skazanych na karę pozbawienia wolności, „Nowa Kodyfikacja Prawa Karnego", vol. XXII, AUW No 3027, Wrocław 2008, p. 179.

${ }^{40}$ P. Pałaszewski, Przyjęcie tymczasowo aresztowanych do aresztu śledczego, „Nowa Kodyfikacja Prawa Karnego", vol. XXV, AUW No 3165, Wrocław 2009, p. 228. 
course of criminal proceedings, maintaining order, safety and discipline and to ensure proper living, sanitary and health conditions ${ }^{41}$.

\section{Obligation to perform cleaning work within the premises of the detention centre}

Article 218 paragraph 1 of the EPC provides for a fairly general obligation of the detainees to perform cleaning work within the premises of the detention centre. This formulation requires a comment, since the basic terms are not defined in this case. According to K. Postulski, "for the cleaning work (Article 218 paragraph 1, first sentence, of the EPC) performed within the premises of the detention centre, for not more than 90 hours a month, a detainee shall not be entitled to a monthly remuneration (Article 123a $\$ 1$ in conjunction with Article 209 of the EPC)"'42. However, the author has failed to clarify what seems to be the most important in the case discussed i.e. the meaning of the term "cleaning work". In addition, there is no legal definition of the "cleaning work" performed at the detention centre or prison. Therefore, it should be assumed that such work may be carried out by detainees (the same with convicts) in order to maintain the order, hygiene and cleanliness of the detention facilities. In practice, these activities include cleaning of cells, corridors, rooms used by the detainees, removing impurities, snow removal, raking leaves, or lawn mowing. Such solutions have been adopted at detention centres, as no external cleaning companies are employed to clean the facilities. Additionally, no consent of the detainee is not required unless they perform the cleaning work for more than 90 hours per month. On the other hand, if the time of the cleaning work was exceeded, then a detainee would be able to lodge a claim against the detention centre for payment for the work carried out in excess of the limit prescribed. Hence, the detention centre administration maintains the "working time" records for the detainees who carry out the cleaning work. In addition, attention should be paid to the locations, where the work is carried out, which include only the premises of the detention centre, and no outside areas. In such a case, it is impossible to perform these works outside at the entry to the detention centre or around the prison walls ${ }^{43}$.

${ }^{41}$ S. Pich, E. Żywucka-Kozłowska, Wykonywanie tymczasowego aresztowania - aspekty penitencjarnej procedury resocjalizacyjnej, Krakow 2007, p. 76.

${ }^{42}$ K. Postulski, Kodeks karny wykonawczy, p. 1077.

${ }_{43}$ M. Kuć, M. Gałązka, Prawo karne wykonawcze, pp. 211-212. 


\section{Conclusions}

Maintaining a balance between the rights of those detained in custody and the obligations imposed on them undoubtedly falls within the domain of public authority and simultaneously is a measure of the level of democratization for each country. In terms of solutions developed in Poland, the catalogue of rights vested with the persons from this category has been quite clearly defined and furthermore they have been granted the rights to notification of the whereabouts (vide detention centre), use their own clothing, food, medical and hygiene products and to exercise their right of defence, in the material and formal sense, as well as the right to employment (not work). On the other hand (but not in opposition to the rights of the detainees), the legislator obliged the those detained on remand to observe the internal regulations and rules of order as well as to carry out cleaning work at the premises of the detention centre. It would be difficult to challenge such an arrangement of various kinds of rights and obligations of detainees, as these are the logical consequence of recognizing the human dignity of every person as the basis for his/her rights and freedoms. Such conclusions are drawn also when taking into account not only in the foregoing reasoning, but also in view of the legal status of detainees and their right to be treated as innocent until finally found guilty by the court. Hence, the legislator (EPC) decided to strengthen the rights of those persons related to the rights of defence, although this type of protection has also been taken into account in the criminal and procedural legislation. Furthermore, the detainees' rights to use their own clothing, food and medicinal and hygienic products from outside of the detention centres (under other conditions than those applicable to convicts) may be evaluated in terms of certain improvements for the detainees themselves. However, the exercise of some of the rights of detainees may be impeded. Limitation of telephone contacts with a defence counsel, difficulties in establishing such a contact and notification of the detainee's whereabouts (especially for foreigners) and limitations applicable to parcels are merely the examples that may indicate the failure of the state's policy towards persons detained in custody. Hence, it is important to recognize that the set of obligations associated with the need for prisoners to comply with the rules of order and internal regulations and to perform the cleaning work may be a sufficient argument for opponents of excessive restrictions on these persons. This, nevertheless, does not affect the need for the ongoing monitoring of how these rights and obligations are exercised by the courts and prosecutor's offices as well as other state and international authorities. 


\section{Bibliografia}

\section{Akty prawne}

Konstytucja Rzeczypospolitej Polskiej z dnia 2 kwietnia 1997 r., Dz. U. Nr 78, poz. 483, z późn. zm. Ustawa z 6 czerwca 1997 r. - Kodeks karny, Dz. U. Nr 90, poz. 555, z późn. zm.

Ustawa z 6 czerwca 1997 r. - Kodeks postępowania karnego, Dz. U. Nr 90, poz. 556, z późn.zm.

Ustawa z 6 czerwca 1997 r. - Kodeks karny wykonawczy, Dz. U. Nr 90, poz. 557.

Rozporządzenie Ministra Sprawiedliwości z 25 sierpnia 2003 r. w sprawie regulaminu organizacyjno-porządkowego wykonywania tymczasowego aresztowania, Dz. U. Nr 152, poz. 1494.

Rozporządzenie Ministra Sprawiedliwości z 2 września 2003 r. w sprawie określenia wartości dziennej normy wyżywienia oraz rodzaju diet wydawanych osobom osadzonym w zakładach karnych i aresztach śledczych, Dz. U. Nr 167, poz. 1633, z późn. zm.

Rozporządzenie Ministra Sprawiedliwości z 27 października 2003 r. w sprawie czynności administracyjnych i rozliczeń finansowych związanych z prowadzeniem depozytu przedmiotów wartościowych i środków pieniężnych osób pozbawionych wolności, Dz. U. Nr 192, poz. 1881.

\section{Literatura}

Bogunia L., Kluczowe zagadnienia wykonywania tymczasowego aresztowania, „Nowa Kodyfikacja Prawa Karnego", t. XVIII, Wrocław 2005.

Bulenda T., Hołda Z., Rzepliński A., Prawa człowieka a zatrzymanie i tymczasowe aresztowanie w polskim prawie i praktyce jego stosowania, „Archiwum Kryminologii” 1992, t. XVIII.

Dudek D., Konstytucyjna wolność człowieka a tymczasowe aresztowanie, Lublin 1999.

Eichstaedt K., Wykonanie postanowienia o zastosowaniu i przedłużeniu okresu tymczasowego aresztowania, "Prokuratura i Prawo" Nr 4/2009.

Horna O., Bezpieczeństwo jednostek penitencjarnych a zadania dla personelu, [w:] W. Ambrozik, H. Machel, P. Stępniak (red.), Misja Służby Więziennej a jej zadania wobec aktualnej polityki karnej i oczekiwań społecznych, Poznań-Gdańsk-Warszawa 2008.

Kalisz T., Wybrane problemy zwiqzane z wykonywaniem tymczasowego aresztowania: status prawny osoby tymczasowo aresztowanej, [w:] B. Stańdo- Kalisz T., Zatrudnianie nieodpłatne skazanych na karę pozbawienia wolności, "Nowa Kodyfikacja Prawa Karnego”, t. XXII, AUW Nr 3027, Wrocław 2008.

Kolendowska-Matejczuk M., Konstytucyjne prawo do obrony w działalności Rzecznika Praw Obywatelskich, Warszawa 2013.

Kosonoga J., Podstawy stosowania środków zapobiegawczych, „Prokuratura i Prawo” 2003, nr 10.

Kawecka A., K. Krajewski (red.), Problemy penologii i praw człowieka na poczq̨tku XXI stulecia: Księga poświęcona pamięci Profesora Zbigniewa Hołdy, Warszawa 2011.

Kowaluk K., Dodatkowy sposób realizacji paczek z żywnościq̨ dla osadzonych, „Forum Penitencjarne” nr 2/2012.

Kuć M., Gałązka M., Prawo karne wykonawcze, Warszawa 2009.

Kumaniecki K. (opr.), Słownik łacińsko-polski, Warszawa 1997.

Łupińska A., Krzysztof Olkowicz zastępcq RPO, „Forum Penitencjarne” nr 10/2015.

Nowak P., Zasady porozumiewania się zatrzymanego z adwokatem oraz tymczasowo aresztowanego z obrońca w Kodeksie postępowania karnego w aspekcie konstytucyjnym oraz prawnomiędzynarodowym, "Czasopismo Prawa Karnego i Nauk Penalnych", z. 1/2013.

Nowicki M. A., Wokół konwencji europejskiej. Komentarz do Europejskiej Konwencji Praw Człowieka, Warszawa 2009.

Pałaszewski P., Przyjęcie tymczasowo aresztowanych do aresztu śledczego, „Nowa Kodyfikacja Prawa Karnego", t. XXV, AUW Nr 3165, Wrocław 2009. 
Pich S., Żywucka-Kozłowska E., Wykonywanie tymczasowego aresztowania-aspekty penitencjarnej procedury resocjalizacyjnej, Kraków 2007.

Płachta M., Prawnomiędzynarodowe i konstytucyjne podstawy ochrony praw oskarżonego w procesie karnym, "Gdańskie Studia Prawnicze" 1999, t. IV

Postulski K., Kodeks karny wykonawczy. Komentarz, Warszawa 2015.

Przybyliński S., Więźniowie "Niebezpieczni"- ukryty świat penitencjarny, Kraków 2012.

Stefański R., Środki zapobiegawcze w nowym kodeksie postępowania karnego, Warszawa 1998.

Szymanowski T., Bezpieczeństwo w wykonywaniu kary pozbawienia wolności i tymczasowego aresztowania w świetle przepisów prawa, [w:] T. Bulenda, A. Rzepliński (red.), Modernizowanie więziennictwa. V Kongres Penitencjarny, Warszawa 2015.

Śledzik W. (red.), Prawo penitencjarne. Kodeks karny wykonawczy z przepisami wykonawczymi izwiqzkowymi, Zakamycze 2006.

Tarnowska D., Prawo tymczasowo aresztowanego oskarżonego do kontaktowania się ze swoim obrońca, "Prawo i Prokuratura" nr 12/2003.

Wałach J., Uprawnienia procesowe zatrzymanego i tymczasowo aresztowanego w świetle zasady prawa do obrony, Białystok 2014.

Wierzbicki J., Telefony dla tymczasowo aresztowanych?, „Forum Penitencjarne” nr 8/2014.

Wiliński P., Zasada prawa do obrony w polskim procesie karnym, Kraków 2006.

Zagórski J., Wykonywanie tymczasowych aresztowań w Polsce, „Państwo i Prawo” 2007, z. 10.

\section{Źródła internetowe}

www.sw.gov.pl/Data/Files/kunickim/informatory-dla-cudzoziemców/polski_2014.pdf www.poznan.pr.gov.pl/?m=prawa-i-obowiazki-podejrzanego\&ide $=29$

www.zamuramizk.pun.pl/as-myslowice-251.htm

\section{Streszczenie}

Przyjęty przez ustawodawcę katalog uprawnień i obowiązków osób tymczasowo aresztowanych uwzględnia konstytucyjną zasadę zakazu naruszania godności ludzkiej. W Kodeksie karnym wykonawczym uwzględniono prawo aresztanta do powiadomienia o miejscu swojego pobytu, prawo do obrony, prawo do korzystania z wyżywienia, środków leczniczych i higienicznych otrzymywanych spoza aresztu śledczego i prawo do zatrudnienia. Natomiast do podstawowych obowiązków tymczasowo aresztowanych zaliczono przestrzeganie postanowień regulaminowych i porządkowych oraz wykonywanie prac porządkowych w obrębie aresztu śledczego. Jednak realizacja powyższych uprawnień oraz egzekwowanie obowiązków nastręcza trudności związane z wykonywaniem tych przepisów, przez co ogranicza się wolności obywatelskie.

Słowa kluczowe: tymczasowo aresztowani, prawa, obowiązki.

\section{Rights versus obligations of persons detained in custody in Poland}

\section{Summary}

The catalogue of rights and obligations of the persons detained in custody takes into account the constitutional prohibition to violate the human dignity. The Executive Penal Code provides for the right of a person detained in custody to notify his/her place of residence, the right of defence, the right to use food, medical and hygienic resources received outside of the pre-trial detention 
centre and the right to employment. On the other hand, the basic duties of the detainees included the observance of the detention centre rules and regulations as well as the cleaning works within the detention centre. However, the exercise of these powers and the enforcement of obligations are difficult to enforce, thus limiting civil liberties.

Keywords: detained in custody, rights, obligations. 